\title{
Political Rights in Accordance with the UN and Council of Europe System for Protection of Human Rights: Free Elections
}

\author{
Elena Andreevska ${ }^{1}$
}

\begin{abstract}
The »first generation of human rights«, which is based on the classical human rights concept of the Enlightenment, includes not only civil but also political rights. In essence, civil rights constitute liberal, individual rights to ward off state interference. Political rights, on the other hand, guarantee a claim by the individual to participation in the process of political decision making, and this requires not only that the state refrain from certain acts but also that it take certain positive steps. Electoral rights are both collective and individual in nature, they are rights of »the people « and, at the same time, the rights of every individual citizen. Elections must be free. This does not exclude the possibility of voting being compulsory: the freedom with which we are concerned here is not the freedom to participate or not to participate in the vote, but the freedom of electoral choice.
\end{abstract}

Keywords: Free elections, electoral rights, democracy, political rights

\section{Introduction}

$\mathrm{T}$ The right to participate in civic life is at the heart of human rights and is a foundation of the principles, visions and values reflected in international standards. Democracy is usually translated as the rule of the people. However, democracy is more complex in its definition. It is a form of government, it is also an idea which underlines the socio-political and legal organization of the state, it can be seen as an ideology, it appears in the form of many different models both in reality and in scientific theory, encompassing many different meanings.

Yet, in its essence, democracy is strongly related to the principles of human rights and cannot function without assuring the full respect and protection of human dignity. Apart from participation and representation, it is also about inclusion - the right to be fully included in the civic life of one's community, one's region or one's state. How fully an individual citizen exercises the right to be included and to participate is at the citizen's own discretion, but the right cannot be denied. Along with inclusion, the notion of pluralism is at the heart of democratic governance. Pluralism means overcoming >otherness and affirming that people with different currents of human experience can live together in dignity, under the rule of law, where diversity is seen as a source of strength and resiliency. In essence, nobody with a justified claim to citizenship or other forms of legal residence can be denied inclusion and human dignity. This is a litmus test of democracy. ${ }^{2}$

Moreover, the human security agenda focuses on attaining freedom from pervasive threats to people's lives or livelihood, be they political, social or economic. Respect for human rights and democratic freedoms as well as empowerment for human development are indispensable for safeguarding and promoting human security. The advancement of human rights, human development and human security - three overlapping and inter-

1 Professor, SEE-University, Tetovo, Macedonia, E-mail:e.andreevska@seeu.edu. mk.

2 Benedek, W., Understanding Human Rights: Manuel on Human Rights Education (ETC, 2006), pp. 319-320. linked concepts that are at the core of a vision for an innovative world order - can indeed only take root in societies in which the democratic values are both propagated and practiced.

Only in democracy, the respect for human rights implies freedom from fear and threats to one's fundamental existence. Human development asserts a claim to the resources and freedoms one needs to fully develop one's human potential. Human security evokes freedom from hunger, war, ecological disaster, corrupt governance and other impediments to a life lived in justice and solidarity, with equality of opportunity.

Only equitable, free and democratic participation in political, social and economic life of state or community can promote human security. Only the full guarantee of human rights, participatory governance, the rule of law, sustainable development and equal access to resources can assure that human security turns from a new diplomatic paradigm to a broad basis for democratic decision making and international cooperation. ${ }^{3}$ The universal recognition of political rights constitutes an attempt to make the political ideal of democracy binding under international law at the level of individual enforceable human rights. This is a profound advance in the international protection of those fundamental values of human coexistence that we term human rights.

With the fall of the Berlin Wall in 1989 and the collapse of communism in Central and Eastern Europe, it seemed that democracy had indeed succeeded. However, still not all of the countries which theoretically endorse democracy as form of government pay full respect to democratic principles or live democracy in practice. ${ }^{4}$

3 Ibid. Supra 1, p. 321.

4 The first modern democratic state was established in the USA, whereas France was the first European state to be found on democratic principles, following the French Revolution. After 1945, there has been a spread of liberal democracy both in Europe and across the world, often replacing authoritarian government. 
There are a number of key elements which constitute the basis of every democratic society ${ }^{5}$ among which the political pluralism and free elections are very important. Only political pluralism can secure structures flexible enough to adapt to changing needs but which still remain a stable ground for democratic governance. Moreover, the division of powers, introduced as a concept by John Locke ${ }^{6}$ is a fundamental principle of modern democracies. $^{7}$

The past three decades have seen a dramatic global expansion of democracy, which has led to an extraordinary focus on the institution of elections. In countries around the world, elections have served to help resolve long-standing conflicts and to initiate or consolidate transitions to democracy. Free and fair elections increase the likelihood of a peaceful transfer of power. They help to ensure that losing candidates will accept the validity of the election's results and cede power to the new government. While elections alone do not assure democracy, since dictators can use the resources of the state to tamper with the election process, they are the pillar of democratic government.

The right of everyone to take part in the government of his or her country has a solid foundation in international law. It is proclaimed in the Universal Declaration of Human Rights (UDHR) in the following terms:

(3) The will of the people shall be the basis of authority of government; this will shall expressed in periodic and genuine elections which shall be held by secret vote or by equivalent free voting procedures.

However, when one speaks of political rights in international law strictu senso, it is less clear what is covered. Article 25 of the Covenant on Civil and Political Rights ${ }^{8}$ (Covenant) contains a list of political rights, which include the right to take part in the conduct of public affairs, suffrage and equal access to public service. International instruments, which supplement the Universal Declaration of Human Rights and the Covenant establish two essential conditions for democratic elections: (1) universal and equal suffrage and (2) a secret ballot. International conventions banning discrimination based on race or gender further reinforce the right to participate in elections on the basis of >universal and equal suffrage . To be >free and fair<, however, the elections also must meet a number of other standards. ${ }^{9}$ This text looks at the standards set in two most relevant legal documents.

5 Equality; participation; majority rule and minority rights; rule of law and fair trial; commitment to human rights; political pluralism; free elections; and division of powers.

6 See Locke, J., Two Treatises on Government (1960)

7 According to this principle, state power is divided into legislative, executive and judicial bodies functioning independently but accountable to each other and to the people.

8 GA Res. 2200/A (XXI).

9 For an election process to be free, citizens must have the right and opportunity to choose. There must be freedom of assembly, association, movement and speech, for candidates, parties, voters, media, observers and others. The political environment should be free of intimidation. Such freedom is an essential precondition to meaningful elections.

\section{Electoral Rights: Article 3 of Protocol 1 to the European Convention on Human Rights}

By Article 3 of Protocol No. 1 the Contracting Parties undertook >to hold free elections at reasonable intervals by secret ballot, under conditions which will ensure the free expression of the opinion of the people in the choice of the legislature .

Article 3 would seem to guarantee electoral rights only as regards sthe choice of the legislation $\triangleleft .{ }^{10}$ The importance of Article 3 does not consist in the first place in the obligation of the states to hold free elections at reasonable intervals by secret ballot, but in the connection between those elections and the composition of the legislature. In fact, this means, as was observed by the Commission in its report in the Greek Case, that Article 3 presupposes the existence of a representative legislature, elected at reasonable intervals, as the basis of democratic society. ${ }^{11}$ Moreover, the word legislature >does not necessarily mean only the national parliament $<, 12$ but may equally apply to the legislative organs of the constituent entities of a state with a federal structure. ${ }^{13}$ The Commission has always ruled out the application of Article 3 to assemblies which sexercise no legislative power $\triangleleft{ }^{14}$ It has therefore declared inadmissible complaints concerning the method of formation of organs of local or regional communities, which exercise no more than a regulatory power delegated by parliament, and do so subject ultimately to the latter's supervision. ${ }^{15}$ It also takes the view that Article 3 does not apply the organs of public-law professional corporation, even if certain regulatory powers have been conferred on it. ${ }^{16}$

Since such an important role has been assigned to the national legislature in ensuring the enjoyment of the rights and freedoms set forth in the Convention as well as in subjecting certain of these rights and freedoms to rules which may restrict their enjoyment, it is of eminent importance that this legislature should consist of democratically elected representatives of the holders of those rights and freedoms. Therefore, properly speaking, this Article 3 should have preceded the provisions of Section I of the Convention as a further elaboration of the concept of seffective political democracy< referred to in the preamble and of >democratic society< mentioned in various provisions of the Convention. In its first judgment with regard to Article 3 of Protocol No. 1 the court emphasized that since it enshrines a characteristic principle of democracy, Article 3 of Protocol No. 1 is accordingly of prima importance in the Convention system ${ }^{17}{ }^{17}$

Moreover, the states parties also seem to be under a duty to guarantee the rights secured under Article 3 of Protocol No. 1 in respect to the election of their representatives to the Eu-

10 See Comm.7096/75, X v. United Kingdom, decision of 3 October 1975, DR 3, p.165 at p. 166.

11 Report of 5 November 1969, Yearbook XII, Vol. 2 (1969), p. 179.

12 Mathieu-Mohin and Clerfayt case, Judgment of 2 March 1987, Series A. No. 113.

13 This is in particular the case of German or Austrian parliamentary assemblies.

14 Comm. 6745/74 and 6746/74.

15 Comm.5155/71, X. v. United Kingdom, decision of 12 July 1976, DR 6, p. 13 at pp. 13-14.

16 Comm. 9926/82, X. v. Netherlands, decision of 1 March 1983, DR 32. p. 274 at p. 278.

17 Judgement of 2 March 1987, Mathieu-Mohin and Clerfayt, A.113, p. 22. 
ropean Parliament. The Commission has given its opinion on application concerning the electoral system pertaining to this body, notwithstanding some hesitation on the applicability of the Protocol in this connection. ${ }^{18}$ This hesitation is difficult to understand since the European Parliament has already, despite its yet limited powers, the character of a representative organ spartly assuming the powers and functions of national legislatures $<.{ }^{19}$ As the Commission itself has very appropriately pointed out, $>$ it is inadmissible that transfers of power should at the same time enable the High Contracting Parties to exclude areas normally covered by the Convention from the guarantees set forth therein ${ }^{20}{ }^{20}$

Insofar as it refers only to selections and the schoice of the legislature $<$, Article 3 would not appear to concern referenda, at least at first sight. This indeed appears to be the opinion of the Commission. Finding that the 1975 British referendum on membership of the European Communities >was not an election concerning the choice of the legislature < but >was of purely consultative character and [that] there was no legal obligation to organize such a referendum<, it took the view that the referendum could not sfall within the scope of Article 3 < of Protocol 1 and that a right to participate therein $>$ could not be derived from that provision either. ${ }^{21}$

In addition, access to governmental functions, and in particular to those of Head of State or of Government, would appear to fall outside the scope of Article 3. For example, under various versions envisaged in the course of its drafting, it was proposed to guarantee that the opinion of the population should be represented by the `Government as well as by the legislature ${ }^{2}{ }^{22}$ but the reference to >Government was abandoned, it being observed that the choice of Government need not >necessarily [be] made directly by the people $\iota^{23}$

It is clear that this article does not require holders of government offices to be directly elected by the people. However, when they are chosen in this manner, the same question arises as in connection with a referendum and the consultation of people, namely, should not the election in question be affected

18 Comm.8364/78, Lindsay and others $v$. The United Kingdom, decision of 8 March 1979, DR 15, p. 247 at p. 250; Alliance des Belges de la Communate Europenne v. Belgium,decision of 10 May 1979, DR 15, p. 259 at p. 261.

19 Ibid.

20 Comm. 11123/84, Tete v. France, decision of 9 December 1987, DR 54, p. 52 at p.59; 11406/85, Fournier v. France, decision of 10 March 1988, DR 55, p. 130 at p. 134.

21 Comm.. 7096/75 (X) v. United Kingdom, decision of 3 October 1975, DR 3, p. 165 at p. 166. This is perhaps debatable. It may be true that, as the Commission stated, sthe Convention does not guarantee such a general right of consultation to the population<. See Comm. 6742/94, X v. Federal Republic of Germany, decision of 10 July 1975, DR 3, p. 98 at p. 103: >In particular Article 3 of the First Protocol ... . does not impose on States an obligation to consult the population before the conclusion of an international treaty<. Similarly it may be true that it does not guarantee any >general right < for everything to be submitted to the decision of the people. It may also be that recognition of rights of this nature is ' governed exclusively by the internal constitutional law of the State in question $<$. But does this mean that it was necessary to maintain that the Convention sdoes not guarantee the right to self-determination'? This right is, of course, not mentioned in Article 3 of Protocol No. 1, but does not this provision, indeed the whole Convention, presuppose it? Is it not the very foundation of what the preamble of that instrument describes as an seffective political democracy'?

22 Macdonald, R.St.J., and Petzold, H., The European System for the Protection of Human Rights (Martinus Njhoff, 1993), p. 557.

23 In connection with an application challenging the method of electing the Federal President in Austria, the Commission left open the question of the applicability of Article 3 to this election. Ibid. in accordance with the requirements which apply to the choice of the legislature, including reasonable intervals'? ${ }^{24}$

\subsection{Scope of the Right to Vote and to be Elected: Principles and Limits}

The electoral rights enshrined in Article 3 of Protocol No. 1 are both collective and individual in nature: they are rights of the people and at the same time the rights of every individual citizen. ${ }^{25}$ On the basis of the formulation of Article 3 as a government undertaking to do something, and not as an individual right, some authors have taken the position that this provision can only be the object of a complaint by a state and not by an individual. ${ }^{26}$ Looking at from the point of view of an individual, electoral rights are plainly in substance the right to elect and the right to be elected; in other words, the right to vote and the right to stand for election. For some time the Commission took the view that these rights were not guaranteed as such under Article 3 of Protocol No.1, or by other provisions of the Convention or other Protocols. ${ }^{27}$

At first the Commission drew from the text of Article 3 the general conclusion that this provision does not imply a right of individual citizens to vote and to be elected. Exclusion from the franchise, not only of particular persons, ${ }^{28}$ but also of groups of persons, ${ }^{29}$ was therefore considered admissible by the Commission on the ground that such exclusion does not prevent the free expression of the opinion of the people in the choice of the legislature ${ }^{30}$

However, it has acknowledged already in 1967, that this undertaking >implies the recognition of universal suffrage $<$ and, from 1975, that the right defined by Article 3 of Protocol No. 1 >is in the nature of an individual rights, since this quality constitutes the very foundation of the whole Convention< and that the provision concerned guarantees in principle the right to vote and the right to stand for election in the legislature. In the Mathieu-Mohin and Clerfayt judgement the court sapproved this latter concept $<.{ }^{31}$ But, as the court also stated in this judgment, the rights in question are not absolute $\triangleleft{ }^{32}$ The Commission had already accepted that States might impose certain restrictions

24 Ibid.

25 It was apparently in particular the collective aspect which was considered in the Greek case. That case gave rise to the finding of a violation of Article 3 of Protocol No. 1 in as much as, in the situation created by the coup d'etat of April 1967, the `Greek people`had been ’prevented from expression their political opinion by choosing a legislature in accordance with Article 3 .. The Commission noted in particular that the elections for the renewal of the parliament, dissolved shortly after the coup d'etat, had been cancelled, that there was no longer any elected legislature, that the election of a new legislature had been postponed sine die and that the political parties had been prohibited and could not be recognized. Nevertheless, fundamentally, it was at the same time the electoral rights of each and every individual Greek citizen which had been infringed upon. See Ibid. Supra 33.

26 Van Dijk, P., and van Hoof, G.J.H., Theory and Practice of the European Convention on Human Rights (Kluwer Law International,1998), p.658.

27 Comm. 530/59, X v. Federal Republic of Germany, decision of 4 January 1960, p. 185 at p. 191; 1065/61, X v. Belgium, decision of 30 May 1961, p.261 at p. 269.

28 Comm. 530/59, X v. Federal Republic of Germany, Yearbook III (1960), p.184, and of collaborator: Comm. 787/60, X v. the Netherlands, Coll. 7 (1962), p. 75.

29 Comm. 1065/61, X v. Belgium, Yearbook IV (1961), p. 260.

30 Ibid.

31 Judgement of 2 March 1987, A. 113, p. 23

32 Ibid., p. 52. 
on the right to vote and the right to stand, provided that they are not arbitrary and do not interfere with the free expression of the people's opinion $\ll{ }^{33}$

The exercise of the right to vote and the right to stand is normally subject to conditions regarding nationality, age and residence. Such conditions are, in principle, entirely legitimate and seldom give rise to any difficulties. In several cases, the court has been called upon to rule on complaints concerning the requirement of residence. It has decided, in relation to applications in connection with elections to the House of Commons, that the requirement whereby a citizen must be resident in a constituency before he can be registered as a elector is sa reasonable administrative requirement $\varsigma .{ }^{34}$ It therefore rejected the complaints submitted in this regard by British nationals who complained that they had not been able to participate in the elections in question under this rule because they were resident abroad. ${ }^{35}$

In addition, many legislations contain the provision that nationals can take part in elections in the country in question only if they also have residence in that country. The Commission considered these requirements as being in conformity with Article 3, and advanced the following justifications for such a restriction: (1)non-residents are less directly and continuously concerned with and less well informed on the day-by-day problems in the country; (2) candidates for the elections have less easy access to non-residents to present the different electoral issues so as to secure a free expression of opinion; (3) non-residence have less influence on the selection of candidates and the formulation of their electoral programs; and (4) the correlation between the right to vote and the involvement in acts of the bodies elected is less. ${ }^{36}$

Moreover, certain categories of persons may be excluded from the exercise of electoral rights for legitimate reasons and provided that the free expression of the opinion of the people ${ }^{37}$ is not impaired. This may be case inter alia, of convicted persons who are serving their sentence ${ }^{38}$ or of persons who have received a specific sentence or were convicted for certain specific offences. Thus, for example, in the case of Dutch conscientious objector, who complained about a rule in the Netherlands according to which every prison sentence of more than one year automatically resulted in a suspension of the exercise of the right to vote for three years, the Commission concluded that, taking into account the legislator's margin of appreciation,

33 Comm. 6745/74 and 6746/74, W, X, Y and Zv. Belgium, Yearbook XVIII (1975), p. 245.

34 Comm.5301/71, $X$ and $Y$ v. United Kingdom, decision of 11 October 1973, CD 44 , p. 29 at p. 48.

35 Comm. 7566/76, Xv. United Kingdom, decision of 11 December 1076, DR 9 p. 121 at p. 122; 7730/76, X v. United Kingdom, decision of 28 February 1979, DR 15, p. 137 at p. 139; and 1065/61 X and other v. Belgium, decision of 30 May 1961, Yearbook 4, p. 325 at p. 339.

36 Comm. 7730/76, X v. United Kingdom, DR 15 (1979), p. 137 at p. 139. The fact that, on the other hand, in some countries nationals residing abroad who are working there in the service of their country do have the right to vote, does not in the Commission's opinion constitute discrimination in the sense of Article 14, because in view of their function they still keep a closer link with their country. See Ibid., Comm. 7730/76 (X) noted 47 above.

37 Comm. 2728/66, X v. Federal Republic of Germany, decision of 6 October 1967, Yearbook 10, p. 340.

38 Ibid. such a measure does not go beyond the restrictions justifiable in the context of Article 3 of Protocol No. $1 .^{39}$

Furthermore, the Commission declared inadmissible an application alleging the violation of Article 3 of Protocol No. 1 in relation to the rejection of lists of candidates who had been put forward for the municipal elections in The Hague and Amsterdam by the President and Vice-President of an association prohibited because of its racism and xenophobia. It took the view that seven assuming Article 3 of the First Protocol applies, the applicants cannot avail themselves of the right protected under that provision, having regard to Article 7 of the Convention ${ }^{4}{ }^{40}$

At last, the right to stand for election to the legislature is also not unlimited. Here the same conditions apply as with regard to restrictions of the right to vote. In its decision in $M v$. the United Kingdom, the Commission concluded that the condition that to be eligible one must not be a member of another legislature was not a restriction which was inconsistent with Article 3 of the First Protocol. ${ }^{41}$

\section{Article $\mathbf{2 5}$ of the UN Covenant on Civil an Poli- tical Rights: Universal Suffrage}

Article 25 of the Covenant recognizes and protects the right of every citizen to take part in the conduct of public affairs, the right to vote and to be elected and the right to have access to public service. Whatever form of constitution or government is in force, the Covenant requires States to adopt legislative and other measures necessary to ensure that citizens have an effective opportunity to enjoy the rights it protects. Article 25 lies at the core of democratic government based on the consent of the people and in conformity with the principles of the Covenant. ${ }^{42}$

Any conditions which apply to the exercise of the rights protected by Article 25 should be based on objective and reasonable criteria. For example, it may be reasonable to require a higher age for election or appointment to particular offices than for exercising the right to vote, which should be available to every adult citizen. The exercise of these rights by citizens may not be suspended or excluded except on grounds which are established by law and which are objective and reasonable. ${ }^{43}$

Elections required by Article 25 of the UN Covenant on Civil and Political Rights must be >genuine $<$ and >periodic $<$. Periodic means that elections must be held at regular intervals. Although the specific determination of those intervals rests with state par-

39 Comm. 9914/82, Hv. the Netherlands, DR 33 (1983), p. 241 at pp. 245-246.

40 Comm. 8348/78 and 8406/78, Glimmerveen and Hegenbeek $v$. The Netherlands, decision of 11 Octobaer 1979, DR 18, p. 187 at p. 197.

41 Comm.10316/83, DR 37 (1984), p. 129 at pp. 133-134. The Commission seems to accept that Article 3 also gives protection to candidates who have suffered from irregularities in the way the elections have been conducted, to the extent that there has been an interference with the free expression of the opinion of the people in the choice of the legislature. See Comm. 18997/91, I. Z. v. Greece, DR 76 (1994), p. 65 at p. 68.

42 See the UN Committee on Human Rights, General Comment 25, »The Right to Participate in Public Affairs, Voting Rights and the Right to Equal Access to Public Service, « 1510th meeting (fifty seventh session) (12 July 1996).

43 For example, established mental incapacity may be a ground for denying a person the right to vote or to hold office. Ibid., para. 4 . 
ties, it may be assumed that the customary span of 4 to 6 years may not be exceeded too far. It is more difficult to determine what is meant by genuine elections. ${ }^{44}$ In conjunction with the principle of free elections, genuine elections mean that eligible voters may freely choose among various alternatives - parties, programs or at least several candidates of the uniform party. A choice between candidates of one party constitutes a genuine election only when this system can be justified on the basis of the specific political circumstances in the state concerned, when the structures within the party are pluralistic and when the party represents a broad spectrum of the population. Any other case would represent an unreasonable restriction on the principles of genuine, free elections. ${ }^{45}$

Thus, the principle of universal suffrage, so essential for a democratic, constitutional state, means that the right to vote may not be restricted to certain groups or classes, but rather is a basic right of all individuals. Since completely unrestricted suffrage does not exist in any country in the world, some states spoke out against the adoption of this principle. ${ }^{46} \mathrm{~A}$ certain contradiction can be seen between the principle of universal - unlimited - suffrage in Article 25(b) and the authorization to provide for reasonable restrictions in the introductory section to this provision. ${ }^{47}$

The fact that the Article 25 is the only provision in the Covenant that does not guarantee universal human rights but rather a citizen's right clearly shows that states parties may deny aliens the right to vote. The restriction to the >citizen< stems from the concern of the modern national state, namely, that only those individuals who are attached to their $<$ state by specific bond of citizenship may exercise political rights. ${ }^{48}$

The right to vote at elections and referenda must be established by law and may be subject only to reasonable restrictions, such as setting a minimum age limit for the right to vote. It is unreasonable to restrict the right to vote on the ground of physical disability or to impose literacy, educational or property requirements. Party membership should not be a condition of eligibility to vote, nor a ground of disqualification.

The right of persons to stand for election should not be limited unreasonably by requiring candidates to be members of parties or of specific parties. If a candidate is required to have a minimum number of supporters for nomination this requirement should be reasonable and not act as a barrier to candidacy. Without prejudice to paragraph (1) of article 5 of the Covenant, political opinion may not be used as a ground to deprive any person of the right to stand for election.

44 Even though the travaux preparatories reveal that Article 25 can also be realized in one-party systems, genuine elections require that voters have a certain minimum amount of political influence. See UN Doc. A/C./3/SR.133, SR.134.

45 Ibid., Supra 7, p. 444

46 In Article 3 of Protocol No.1 of ECHR, the right of universal suffrage was not adopted for this reason.

47 'Every citizen shall have the right and opportunity, without any of the distinctions mentioned in article 2 and without unreasonable restrictions: b) To vote and to be elected at genuine periodic elections which shall be universal and equal suffrage...

48 Traditionally speaking, citizenship means not only passive membership in a state community but also active membership. Therefore, reference was often made to so-called sactive citizenship $<$, to which all persons were entitled who were in full possession of civil and political rights. See Nowak, M., Politische Groundrechte (Vienna, 1988).
In conformity with paragraph (b), elections must be conducted fairly and freely on a periodic basis within a framework of laws guaranteeing the effective exercise of voting rights. Persons entitled to vote must be free to vote for any candidate for election and for or against any proposal submitted to referendum or plebiscite, and free to support or to oppose government, without undue influence or coercion of any kind which may distort or inhibit the free expression of the elector's will. Voters should be able to form opinions independently, free of violence or threat of violence, compulsion, inducement or manipulative interference of any kind. Reasonable limitations on campaign expenditure may be justified where this is necessary to ensure that the free choice of voters is not undermined or the democratic process distorted by the disproportionate expenditure on behalf of any candidate or party. The results of genuine elections should be respected and implemented. ${ }^{49}$

Although the Covenant does not impose any particular electoral system, any system operating in a state party must be compatible with the rights protected by Article 25 and must guarantee and give effect to the free expression of the will of the electors. The principle of one person, one vote, must apply, and within the framework of each state's electoral system, the vote of one elector should be equal to the vote of another. The drawing of electoral boundaries and the method of allocating votes should not distort the distribution of voters or discriminate against any group and should not exclude or restrict unreasonably the right of citizens to choose their representatives freely. ${ }^{50}$

\section{Conclusion}

The right to vote is without doubt the most important political right. Every democratic system in which the political decisionmaking process is not, as is sometimes still the case in several Swiss parishes, executed by popular assemblies, is dependent on the election of representatives in parliaments, councils or comparable bodies.

In contrast to Article 3 of Protocol No. 1 to the ECHR, which guarantees the election of legislative organs only, Article 25(b) to the CCPR does not establish which organs are to be filled by election. This decision is subject to states parties within the scope of their respective democratic model. ${ }^{51}$ But under no circumstances may the reverse conclusion be drawn from this difference, namely that executive organs must be also elected. ${ }^{52}$ What is crucial is that those state organs in which both legal and de facto power is concentrated are either directly or indirectly legitimated by elections. In a parliamentary bicameral system, at least the chamber with the main legislative authority must be elected. ${ }^{53}$

Relevant documents thus set clear standards for elections. These provide obligations which states need to observe. Interestingly, the legal basis for citizens to participate in politics is

49 See Ibid., para. 20

50 Ibid., paras. $10-12$ at 17, 19, 21.

51 UN Doc. No. 205/1986, para. 12

52 With respect to community elections, the committee of experts of the Council of Europe seems to draw such a contrary conclusion. See CE Doc. H(70)7,54 (para. 220).

53 Ibid., Supra 7, p. 443. 
not always included in national constitutions. While over $90 \%$ of the world's electoral democracies have included the right to vote in their constitutions, there is, for example, no constitutional right to vote in two of the world's oldest democracies, the United Kingdom and the United States of America, nor in the world's most populous democracy, India.

Even where it is included in constitutions, it is done in different ways. Constitutions can be classified into four categories depending on how they treat the right to vote:

1. Those in which there is no affirmative constitutional right to vote or no legislation with similar weight.

2. Those that establish universal suffrage for the election of sovereign bodies - such as a parliament. ${ }^{54}$

54 The South Korean constitution is representative of these types of constitutions.

Article 41: The National Assembly is composed of members elected by universal, equal, direct, and secret ballot by the citizens.

Article 67: The President is elected by universal, equal, direct, and secret ballot by the people.

Other constitutions within this group specify that the tenets of universal suffrage should be extended to all elected positions. Bulgaria's constitution exemplifies such statutes.

Article 10: All elections and national and local referendums shall be held on the basis of universal, equal, and direct suffrage by secret ballot.

Article 42: Every citizen above the age of 18, with the exception of those placed under judicial interdiction or serving a prison sentence, is free to elect state and local authorities and vote in referenda.
3. Those that provide a general and independent right to vote. ${ }^{55}$

4. Those that not only provide for a right to vote, but also specify government obligations to facilitate citizen participation and/or those that limit the kinds of restrictions the state can place on who is eligible to vote. ${ }^{56}$

While this typology is neither scientific nor comprehensive, the categories are coherent. They reflect different ways in which the universal suffrage is constitutionally enshrined. They thus illustrate how the human right to elections can be formulated, reflecting different circumstances and traditions.

55 An example of this is Article 32 of the Peruvian Constitution. While the Peruvian constitution allows the suspension of the rights of citizenship and thus the right to vote, it also constructs additional barriers against the winnowing of those eligible to vote. Article 32 states that:

Citizens enjoying their civil capacity have the right to vote. The vote is personal, equal, free, secret and obligatory until one is seventy years old. It is optional after this age. All acts that limit or prohibit citizens from exercising their rights are null and punishable. Other constitutions, like that of Suriname, not only attempt to establish tests on the types of restrictions considered constitutional, but also establish the affirmative obligation of the state to promote electoral participation:

Article 54: The State is obliged to register those with voting rights and to convoke them to participate in the elections. The registration of the voters shall serve no other purpose. Those with a right to vote are obliged to cooperate with the registration of the electorate.

56 Article 10 of the Czech constitution is indicative of the type of constitutions in which the right to vote is buttressed by a commitment to international norms:

Promulgated international agreements, the ratification of which has been approved by the parliament and which are binding on the Czech Republic, shall constitute a part of the legal order; should an international agreement make provision contrary to a law, the international agreement shall be applied.

\title{
AFK-Friedensschriften
}

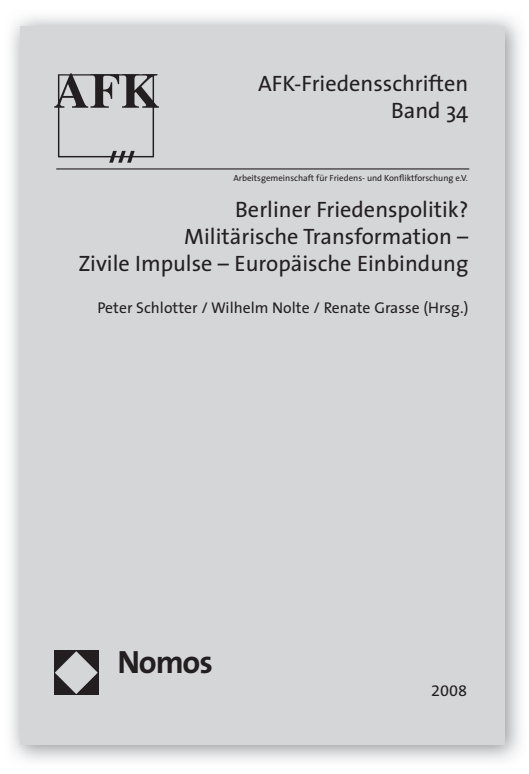

\author{
Berliner Friedenspolitik? Militärische Transformation - \\ Zivile Impulse - Europäische Einbindung \\ Herausgegeben von Peter Schlotter, Wilhelm Nolte und Renate Grasse \\ 2008, Band 34, 363 S., brosch., 29,- €, ISBN 978-3-8329-3434-7
}

War die deutsche Außenpolitik der letzten Jahre am Frieden orientiert - und bleibt sie dies? Der Wandel der Bundeswehr zu einer Armee mit Interventionsauftrag hat das große Risiko mit sich gebracht, den Friedensanspruch der „Berliner Außenpolitik“ zu verfehlen. Diese Gefahr wird auch nicht dadurch aufgewogen, dass in ihr zivile Impulse stärker als früher zum Tragen gekommen sind und die deutsche Politik weiterhin in Europa eingebunden ist.

Bitte bestellen Sie bei Ihrer Buchhandlung oder bei Nomos

Telefon 07221/2104-37 | Fax -43 | www.nomos.de | sabine.horn@nomos.de

Informieren Sie sich im Internet unter www.nomos.de über weitere Bände dieser Schriftenreihe.

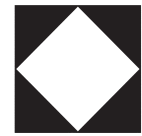

Nomos 